\title{
Managing the geodiversity in Baia Mare region: from the scientific to the public interest
}

\author{
Alexandrina FÜLÖP* \& Marinel KOVACS
}

North University Baia Mare, Mineral Resources and Environment, Dr. Victor Babeş 62A, 430083 Baia Mare, Romania

Received August 2009; accepted December 2009

Available online 27 April 2010

DOI: $10.5038 / 1937-8602.55 .1 .1$

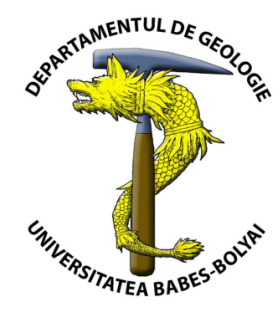

\begin{abstract}
The management of the geodiversity develops around the geological sites with scientific significance, which may be used for education. It is a key component of the natural resources in the Baia Mare region, which encompasses the Oaş and Gutâi Mts. and the adiacent Oaş, Maramureş and Baia Mare basins. After the decline of the mining-derived activities in the region, the development of the scientific and public interest on the geodiversity can be an alternative for the future. The scientific value of the geodiversity in the Baia Mare region is justified by the complex geology of the Neogene magmatic rocks and the according ore deposits. The management of the geodiversity in the Baia Mare region aims towards achieving a data base with detailed geological site inventories and promoting the interest by organizing field trips and courses on different geological topics. The scientific interest may be transferred to the general public, combining geodiversity and biodiversity with culture and entertainment and developing a geotouristic network in the area, beneficial to visitors and for the well-being of the residents.
\end{abstract}

Key words: Geodiversity, Geoconservation, Management, Public awareness, Geotourism, Baia Mare, Romania.

The management of the geodiversity develops around the interest and the conservation of various geological sites, which may bring major benefits for education and science and potentially for the sustainable development of the local communities (Gray, 2004). It is a key component of the natural resources in the region. It is exemplified by the Neogene igneous rocks, associated gold-silver and base metal ore deposits and coeval sedimentary deposits. The interest on the geodiversity was strongly connected to the mining activity which lasted for hundreds of years. Today's Baia Mare, called Rivulus Dominarum in the XIVth century is confronted with the decline of the mining-based activities, strongly reflected by the life of the inhabitants. Searching for alternatives to the mining-connected activities and assessing the geodiversity of the area, it seems that managing the geodiversity could account for the future development.

We need to define it and to testify why the area has been a focus of a major scientific interest. One of the best definitions is given by Stanley (2000) in Brilha (2002): the "geodiversity is the variety of geological environments, phenomena and active processes that make landscapes, rocks, minerals, fossils, soils and other superficial deposits which provide the framework for life on Earth", as well as "the link between people, landscapes and their culture through the interaction of biodiversity with soils, minerals, rocks, fossils, active processes and the built environment". Other definitions are given by Gray (2004) and Kozlowski (2004). Gray (2004) defines the geodiversity as "the natural range (diversity) of geological (rocks, minerals, fossils) geomorphological (landforms, processes) and soil features. *Correspondence: A. Fülöp (alexandrinafulop@yahoo.com)
It includes their assemblages, relationships, properties, interpretations and systems". "Geodiversity is the natural variety of the Earth' surface, referring to geological and geomorphological aspects, soils and surface waters, as well as to other systems created as a result of both natural (endogenic and exogenic) processes and human activity", according to Kozlowski (2004).

According to these definitions, the region of Baia Mare is rich in geological and morphological features formed mainly in the Neogene volcanics, as shown below. This region comprises the Oaş-Gutâi Mts. and the adjacent Oaş, Baia Mare and Maramureş basins (Figs. 1 and 2). Two types of volcanism developed in the Oaş and Gutâi Mts.: a felsic, extensional/"back-arc" type (Badenian-Early Sarmatian) and an intermediate, arc type (Early Sarmatian-Pannonian). The intrusive rock types vary from microgranodiorites to microgabbroes. Some interesting petrological aspects suggest a complex magmatic evolution involving, besides the fractional crystallisation, mixing and mingling processes developed during petrogenesis. Plagioclase and quartz as xenocrysts, crystal clots of pyroxene in felsic rocks and quartz phenocrysts with pyroxene coronas can be observed (Kovacs and Fülöp, 2003).

Comprehensive, well preserved outcrops reveal a series of deposits with features essential in understanding the complex petrological, volcanological and sedimentological processes, as depositional environment. Examples of such deposits, structures and processes are presented below, to testify for the scientific significance of the Baia Mare region. Several volcanic structures have been identified in the Oaş and Gutâi Mts., mostly lava domes, effusive cones 
and a lava plateau. A $15.4 \mathrm{Ma}$, old hidden caldera structure was discover recently in the Gutâi Mts (Fülöp, 2003).

The Badenian rhyolitic welded ignimbrites and the coignimbrite tuffs from Gutâi Mts. are exponents of an early explosive, caldera-related volcanism. The subsequent repeated intracaldera resedimentation built up thick sequence composed of volcaniclastics of pyroclastic origin interbedded with sediments, known for years as "Badenian volcano-sedimentary formation" (Fülöp, 2003). A similar felsic volcanism is exposed in the Maramureş Basin, with evidences of a submarine emplacement of resedimented ignimbrites and co-ignimbrite fallout tuffs (with a high zeolite content), as well as pyroclastic units, suggesting different emplacement mechanisms (Fülöp and Crihan, 2002).

Domes, dome-coulees and complexes of domes can be recognized based on their morphology and the relationship with the surrounding sediments. In the Oaş Mts., most of the dome structures were emplaced in a submarine environment, developing flat topped lavas and quench fragmentation, marginally. Hyaloclastic breccias and phreatomagmatic volcaniclastic deposits, as well as the feeder dykes, are sometimes exposed in quarries.

In the Gutâi Mts., both the structureless lavas, and the lavas with cooling jointings show transitions to volcaniclastics of explosive and non-explosive origin. The thick and extended lava plateau from the northern slope of the mountains shows outcrops of debris flow deposits suggesting hyaloclastic and phreatomagmatic origin. On the southern slope of the mountains, the lava domes show transitions from lavas to hyaloclastites and subsequently reworked hyaloclastites, building up sequences which testify for a subaqueous emplacement. Explosive events developed in connection with dome growth or destruction, explaining the relationship among lavas with the pyroclastic deposits. The gravitational, non-explosive collapse of the structures is characteristic for the Gutâi Mts., indicated by talus breccias, debris flows and debris avalanche.

Overall, there is a large diversity of sedimentary rocks, such as fossiliferous limestones of Cretaceous, Paleogene and Badenian age, Cretaceous and Paleogene red and green marls and Paleogene sandstones and microconglomerates. The Paleogene basement is well represented in the eastern part of the Gutâi Mts., as indicated by the flysch nappes which include the last remains of the Pienniny Klippen Belt. Epithermal ore deposits, mostly vein-type, can be seen in open pits or at specific sites with remarkably exposed hydrothermal alteration. This includes the, for the region typical, adularia-sericite/quartz type, and argillic alteration. Highly silicified rocks, as erosion remnants, developed on the southern border of the Gutâi Mts.

These wide appearances of geological and morphological forms are an open school for geologist and the wide public. Accordingly, more than twenty Ph.D. theses on different geological topics (petrology, ore deposits, volcanology, sedimentology of volcaniclastics, paleontology) were accomplished and many geological field trips and workshops were held in this region, as practical applications for the students or with the occasion of major geological conferences and international projects. These account all for the scientific importance and interest in the geodiversity.

The geodiversity gained recognition much later than the concept of biodiversity but was thought to be sufficiently Studia UBB, Geologia, 2010, 55 (1), 5 - 8 robust not to require protection or management. Unfortunately, it is vulnerable to natural processes and/or engineering work arising from social and economic development, such as the mining activity and the settlement of the people in the mining areas. Geological features exposed in outcrops developed under environmental conditions which vanish with time. They need protection because once destroyed, they will be never recovered. If the geodiversity is "the quality we are trying to conserve", the geoconservation is "the endeavour of trying to conserve it", or the "conservation of non-living parts of the natural environment -geological features, landforms and soils", according to Sharples (2002). "The aim of geoconservation should be to maintain the range of earth science features within their borders", according to Gray (2004) by the "action taken with the intent of conserving and enhancing geological and geomorphological features, processes, sites and specimens, as geoconservation is defined by Burek \& Prosser (2008).

Conserving the geodiversity of the Baia Mare region requires a combination of legal protection of nationally important sites and the protection of any significant geological sites (Brilha, 2002; Sharples, 2002). The management of the geodiversity in the Baia Mare region develops around the concepts of geodiversity and geoconservation, in respect to develop the potential of the natural resources. It is complementary to the management of the biodiversity and to the development of other cultural issues, such as history, archaeology, arts, tradition. Until recently, geodiversity was missing in a holistic approach aiming towards the sustainable development of the local communities (Buckley, 2003).

Four objectives of the management of the geodiversity in the Baia Mare region can be identified:

1. The achievement of a complex data base with detailed geological site inventories. With the help of such inventories based on consistent criteria and detailed description, important sites and their quantity can be identified. Such detailed scientific inventories have to be rigorously completed to gain the acceptance of the scientific community at the national and international level.

2. The promotion of the interest on the geodiversity of the Baia Mare region. To raise the scientific interest of the public is probably the most important action because the increasing interest will have a strong feed-back for conservation and development. The scientific interest on the geodiversity of the Baia Mare region can be increased by advertising the potential of this area to geologists and general public. This potential can be used for field trips and courses focusing on a wide spectrum: Neogene volcanism and sedimentation, Neogene epithermal non-ferrous ore deposits, hydrothermal alterations, volcanic geomorphology, chronology of the volcanic events, etc. The huge potential of the area can be testified by some examples of geosites which may be included in such geological field trips.

As an example, a field trip can be organized in the southern part of the Gutâi Mts., which focuses on the Neogene volcanism and associated epithermal ore deposits and includes the following stops from the West to the East (Fig. 1): (1) Ilba (Badenian sequence of rhyolitic ignimbrite flows and associated fallout tuffs), (2) Nistru (Sarmatian pyroxene andesite lavas with hydrothermal alterations, pierced by a microdiorite intrusion and an outcropping sulphide vein), (3) Firiza (Paleogene, highly tectonized 
sedimentary flysch), (4) Chiuzbaia (fossil flora reserve), (5) Baia Sprie (open pit in the famous base metal ore deposit), (6) Surdeşti (Piatra Roşie sequence of Pannonian dacite volcaniclastics) and (7) Cavnic (pyroxene andesite body and large areas of hydrothermal alteration in the vicinity of ore veins).

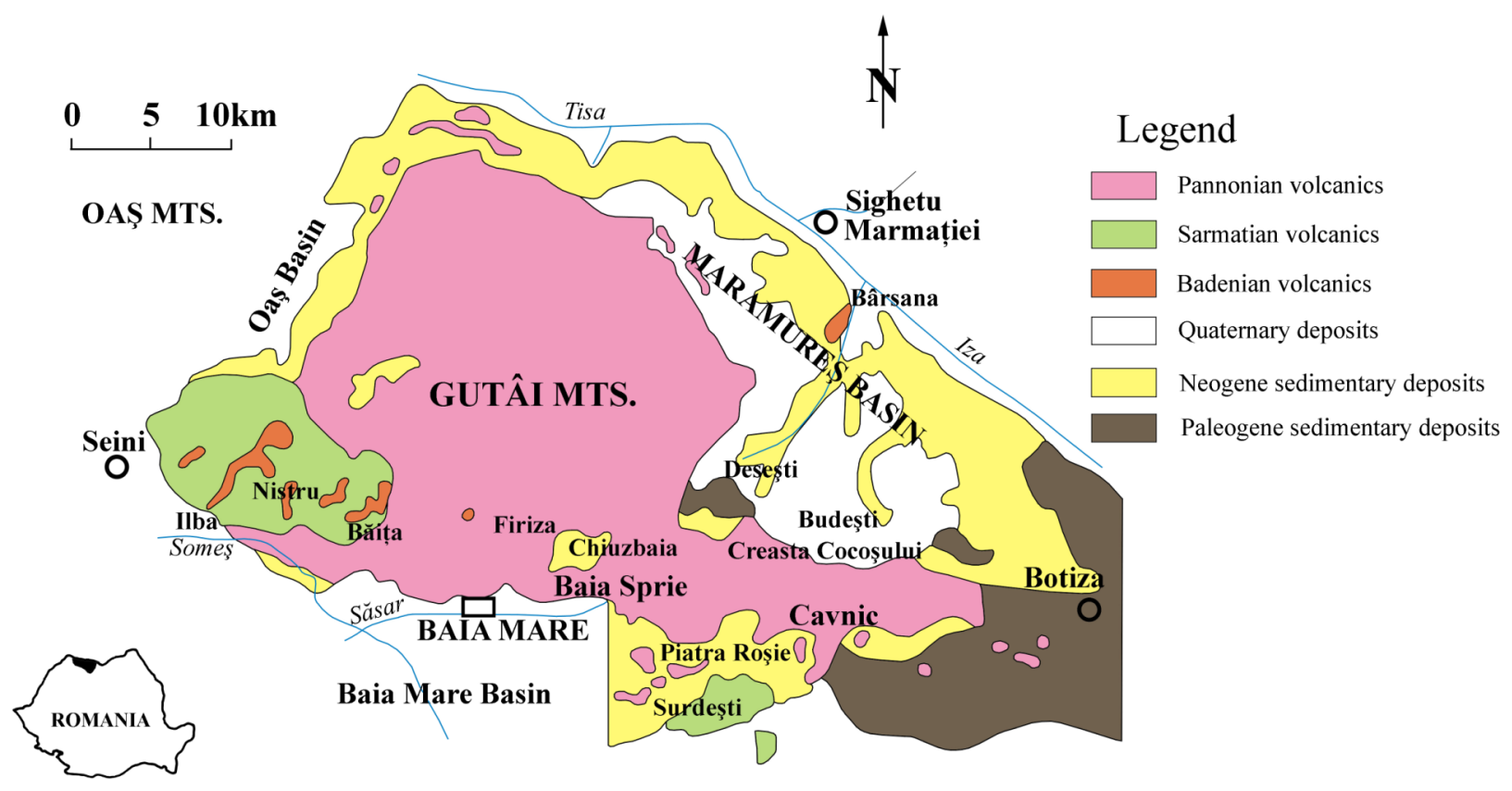

Fig. 1. Geological sketch map of the Gutâi Mts. and the Maramureş Basin. Location of several geosites with geotouristic perspective (simplified after Gabor et al., 1999).

The Badenian felsic explosive volcanism from Gutâi Mts. and Maramureş Basin can be the subject of another field trip. There are many outcrops on the southern border of Gutâi Mts. and the most relevant are as follows (Fig. 1): (1) Ilba (the sequence of the welded ignimbrites overlain by the co-ignimbrites fallout tuffs), (2) Băița (volcaniclastics of pyroclastic origin interbedded with subaqueous, deep water sediments) and (3) Firiza (the easternmost outcrop in the welded ignimbrites showing gas escape structures). In the Maramureş Basin, around the Bârsana village (4), many large outcrops of the Badenian rhyolite volcaniclastics expose the thick sequence of resedimented, stratified ignimbrites with plant remnants and the massive, very thick co-ignimbrite fallout tuffs, with up to $90 \%$ clinoptilolite content. They are overlain by a sequence of volcaniclastics of mass flow origin, slides and slumps of pyroclastic origin, emplaced in a submarine environment.

The features of the extrusive lava domes and their associated volcaniclastics are very well exposed in both, the Oaş and the Gutâi Mts. A potential field trip which starts in Oaş Mts. shows (Fig. 2): (1) Batarci (a partly emergent dacite structure which underwent explosive events and developed subaerial pyroclastic flows and basal hydroplastic flows, suggesting the subsequent resedimentation over the wet sediments), (2) Gherța Mică (a small dacite dome with glassy lavas showing radial columnar jointings, the argillized feeder dyke and the frequent phreatomagmatic breccia veinlets), (3) Turulung (a dacite dome composed of glassy lavas passing to in situ and resedimented hyaloclastic deposits preserving lava lobes enclosed, and to massive and stratified, mostly reworked phreatomagmatic deposits), (4) Oraşu Nou (the rhyolite dome coulee with highly vesicular banded lavas transitional to hyaloclastites with macroperlites and resedimented hyaloclastites with microperlites). The field trip continues in the Gutâi Mts. following the same topic (Fig. 1): (5) Piatra Roşie (structureless dacitic dome laterally connected to a thick sequence of repeatedly reworked hyaloclastic deposits), (6) Creasta Cocoşului (the andesite lava dome with vertical and horizontal cooling joints showing spectacular crenellation due to erosion; it passes laterally into a massive talus breccia deposit emplaced by the gravitational, non-explosive collapse of the volcanic structure).

To become equally important as biodiversity, geodiversity has to increase its public awareness and understanding. Guidebooks promoting elements of the natural and cultural resources of the area may be provided in this respect, conducting people to hike on trails or drive on the roads to discover the geodiversity and the biodiversity, together with old wooden churches, traditional wooden gates, traditional wears and houses, or the Art Museum, the History and Archaeology Museum and the old downtown of Baia Mare, recently restored.

3. The awareness of the local authorities, NGOs and local communities about conserving the geodiversiy. The local authorities, as well as a large number of NGOs from the region and the Environmental Protection Agency are aware of the potential of the geodiversity in the region. The local scientific community needs also to be more actively involved, altogether increasing the number of statutoryprotected areas as well as improving the knowledge and protection of the non-statutory sites.

The local communities should be informed about the importance of the geodiversity and trained to protecting it, being aware of the potential benefits. Local small business is encouraged, as well as civic groups to build partnerships to promote and provide a distinctive, authentic visitor experience and market their locales effectively. 


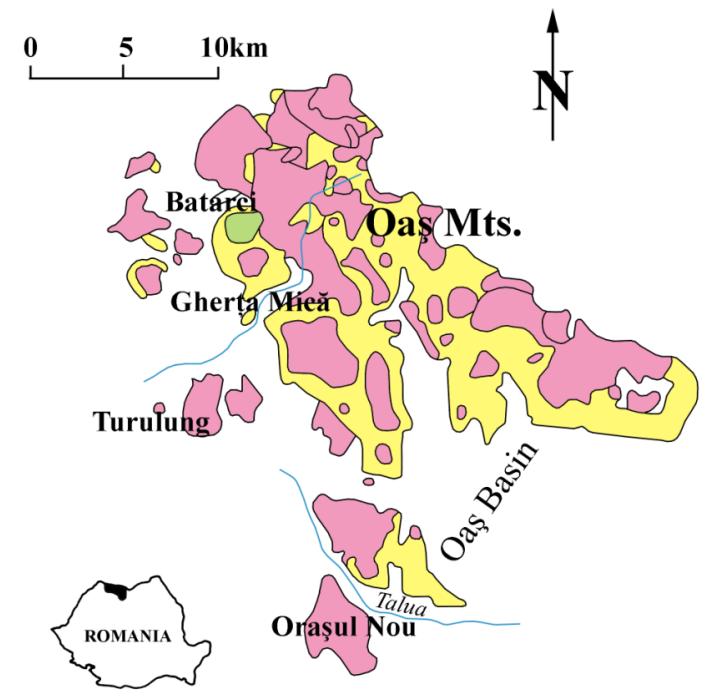

\section{Legend}

Pannonian volcanics

Sarmatian volcanics

Quaternary deposits

Neogene sedimentary deposits

Fig. 2. Geological sketch map of the Oaş Mts. Location of several geosites (simplified after Gabor et al., 1999).

4. Connecting the geodiversity with biodiversity and culture to enhance the character of the region by developing a geotouristic network in the area, beneficial to visitors and for the well-being of the residents. The geotourism is appealing to visitors with wide interests. In this respect, field excursions may be organized, which offer packages combining geodiversity, biodiversity, tradition and arts with recreation. An example of such a field excursion has been given by Fülöp and Kovacs (2006). Other examples can be used in a similar way, e.g., the Creasta Cocoşului ridge, which is a legally protected area, combines spectacular geomorphological features of lavas, lakes, peat bogs and protected birds, with hiking possibilities in a beautiful landscape (Fig. 1). The Maramures Basin gives an example of interference between the explosive volcanism and the deep submarine environment, with economic connotation because of the hosted outstanding zeolite deposit. The tourists may combine geology with a walk along the Maramureş villages, with traditional wooden houses and decorated wooden gates, with visits to wooden churches such as those from Budeşti and Deseşti (both belonging to the UNESCO patrimony) and to some entertainment in a beautiful country side landscape. Similar, combined packages of geodiversity, biodiversity, landscape and culture can be offered in the Cavnic area: the Piatra Roşie Hill shows a sequence of hyaloclastites built up by a lava dome, shattered when flowing into a submarine basin and being repeatedly reworked afterwards. A beautiful sightseeing over the Baia Mare Basin is offered from the top of the hill and close to it, at Şurdeşti, the wooden church with one of the tallest tower from Europe (belonging to the UNESCO patrimony) can be visited (Fig. 1).

Summarizing, the paper assesses briefly the geodiversity of the Baia Mare region and the necessity for geoconservation, as major constraints for a successful management. The objectives of the management are calling for an inventory of the geosites, for the scientific interest of the area, and how geodiversity may become more visible and accessible to the general public. Responsible local institutions and organizations should be equally involved.

The geodiversity management of the Baia Mare region will enhance the value for geotourism, increasing the Studia UBB, Geologia, 2010, 55 (1), 5 - 8 interest and connecting with other elements of natural and cultural resources.

\section{R E F E R E N C E S}

Brilha, J. 2002, Geoconservation and protected areas. Environmental Conservation, 29 (3): 273-276.

Buckley, R. 2003, Research note: Environmental Inputs and Outputs in Ecotourism; Geotourism with a Positive Triple Bottom Line? Journal of Ecotourism, 2 (1): 76-82.

Burek, C.V., Prosser, C.D. 2008, The History of Geoconservation. Geological Society of London Special Publication 300, $312 \mathrm{p}$.

Fülöp, A., Crihan, M. 2002, Middle Miocene acidic volcanism from Maramureş Basin (Northern Romania). Geologica Carpathica, 53 (CD-ROM).

Fülöp, A. 2003, The Beginning of the Volcanism in Gutâi Mts. Paleovolcanological and paleosedimentological reconstructions. Dacia, Cluj Napoca, 134 p (in Romanian).

Fülöp, A., Kovacs, M. 2006, Geotourism in Gutâi Mts., Eastern Carpathians. Environment \& Progress, 6: 187192 (in Romanian).

Gabor, M., Kovacs, M., Edelstein, O., Istvan, D. \& Bernad, A. 1999, Geological map of Oaş-Gutâi-Țibleş Mountains, scale 1:25000. IPEG Maramureş S.A. Archive, Baia Mare (in Romanian, unpublished).

Gray, M. 2004, Geodiversity: Valuing and Conserving Abiotic Nature. John Wiley and Sons, New York, 434 p.

Kovacs, M., Fülöp, A. 2003, Neogene volcanism in Gutâi Mts. (Eastern Carpathians). A review. Studia Universitatis Babeş-Bolyai, Geologia, 48 (1): 3-16.

Kovacs, M., Fülöp, A. 2005, Petrological and volcanological data of Piatra Roşie-Dăneşti extrusive domes in Gutâi Mts. (Eastern Carpathians, Romania). Mineralia Slovaca, 3 (37): 285-287.

Kozlowski, S. 2004, Geodiversity. The concept and scope of geodiversity. Przeglad Geologiczny, 52: 833-837.

Sharples, C. 2002, Concepts and principles of geoconservation, Tasmania, Australia. http://www.parks.tas.gov.au. 